CSURgó BeRnADETT - MegYeSI BOLDIZSÁR ${ }^{1}$

KÉPZELT KÜLÖNBSÉGEK

A VÁROSI ÉS VIDÉKI KÖZÖSSÉGEK, TÁRSAS KAPCSOLATOK KVANTITATÍV VIZSGÁLATA

DOI: 10.18030/socio.hu.2016.3.48

ABSZTRAKT

A jelenkori vidékszociológiai kutatások és a laikus diskurzus egyaránt azt mutatja, hogy a klasszikus vidékváros ellentétpár ma is él, és meghatározó társadalmi gyakorlatokat eredményez. Tanulmányunkban az Integrációs és dezintegrációs folyamatok a magyar társadalomban címú OTKA kutatás keretében létrejött országos reprezentatív adatbázis adatai segítségével azt vizsgáljuk, hogy a vidék-város dichotómia diskurzusban megjelenő különbségek valós vidéki és városi terek objektiv és szubjektív különbségeiben igazolhatók-e. Eredményeink azt mutatják, hogy a térreprezentáció és a térbeli elkülönülés összetett jelenség, amely nem kapcsolható a közösség és tér egy-egy jellegzetes tulajdonságához. Habár jelen vannak a vidékkel kapcsolatos pozitív imázs elemek, de inkább csak részleteikben; ezeket a vidékre jellemzőnek érzett társadalmi problémák és a társadalmi dezintegráció érzés felülírja. A városi elidegenedés pedig az adatok alapján nem igazolható.

Kulcsszavak: vidék-város ellentét, térbeli reprezentáció, közösség, társadalmi tőke

IMAGINED DIFFERENCES

QUANTITATIVE ANALYSIS OF URBAN AND RURAL COMMUNITIES AND SOCIAL RELATIONSHIP

\title{
ABSTRACT
}

Both contemporary rural sociological inquiries and the lay discourses show that the classical rural urban division still exists, and results in visible social practices. In our study we analyse whether the discursive rural urban dichotomy can also be found in the objective and subjective differences between rural and urban spaces, using the representative database of the integrative and disintegrative processes in Hungarian Society OTKA research. Our results show that the representation of space and spatial differences are complex phenomena, which cannot be linked to a typical characteristic of the community or the space. The positive image elements of the rural are fragmented; these are shadowed by social problems typical for the rural and the feeling of social disintegration. Our data do not prove the existence of urban alienation.

Key words: urban-rural division, spatial representation, community, social capital

1 A szerzők, Csurgó Bernadett és Megyesi Boldizsár az MTA TK Szociológia Intézet tudományos főmunkatársai, 2015-2018 között mindketten Bolyai János Kutatási Ösztöndíjban részesülnek. 


\section{KÉPZELT KÜLÖNBSÉGEK}

\section{A VÁROSI ÉS VIDÉKI KÖZÖSSÉGEK, TÁRSAS KAPCSOLATOK KVANTITATÍV VIZSGÁLATA}

\section{BEVEZETŐ}

A jelenkori vidékszociológia egyik alaptézise szerint a vidék-város ellentét társadalmi konstrukció eredménye, a vidék alapvetően reprezentációként létezik, és valójában a társadalmi különbségek nem köthetőek a vidéki és városi terekhez (Cloke 1997, Mormont 1990). Célunk, hogy az Integrációs és dezintegrációs folyamatok a magyar társadalomban című OTKA kutatás keretében létrejött országos reprezentatív adatbázis adatai segítségével teszteljük a fenti állítást. Célunk a vidék és város dichotómia legfontosabb tényezőinek - a közösség fontossága és a társadalmi tőke jellege - alapvető térbeli mintázatainak leíró elemzése.

A klasszikusok, mint Tönnies (2004) Közösség és társadalom című múve, vagy Wirth (1973) urbánus és falusi életmódot szembeállitó elméletében a vidék és közösség fogalma összekapcsolódik. A vidék jelenkori idilli reprezentációjának is az egyik legfontosabb eleme a vidék közösség alapú képzete, amely együtt jár a társadalmi tôke magas szintjével, ahol a gyenge és erős kötések száma egyaránt nagyobb, mint a városban, ugyanígy az általános bizalom szintje is magasabb, különösen a személyközi, interperszonális bizalom erősebb. A város pedig ezekben az elméletekben az elidegenedés tereként jelenik meg. A rendelkezésre álló adatok alkalmasak arra, hogy megvizsgáljuk, valóban igaz-e a tönnies-i és wirth-i tézis, azaz, hogy a városiakra inkább az individualizálódás, a kapcsolatok alacsonyabb száma jellemző, míg a vidékieket a közösség és a társadalmi tőkekapcsolatok nagyobb mértékű jelenléte, sűrűsége jellemzi. Kérdésünk tehát, hogy a város és vidék képzetek a város és vidék különbségéről, amelynek egyik legfontosabb eleme éppen a kapcsolatokhoz és a társadalmi tőkéhez köthető, igazolható-e a rendelkezésre álló adatok² segítségével?

Hipotézisünk szerint a vidék és város - objektiv és szubjektív - különbsége nem igazolható sem a kapcsolathálózati eltérések, sem a közösség és a társadalmi tőke eltéréseit vizsgálva. Amellett érvelünk, hogy a tudományos és köznapi diskurzusban egyaránt jelen lévő vidék-város dichotómia nem azonos a településszerkezeti kategóriák alapján definiálható térrel, bár a társadalmi tőke jellegzetességek és a közösség képzetek alapján definiálható egyfajta térbeli különbség, amely azonban számos ponton metszi a különböző tértípusokat, amely vizsgálatunkban a közigazgatási településkategóriákat és a szubjektív lakóhely tipológiát jelenti. Célunk tehát azoknak a város-vidék dichotómia percepcióhoz kapcsolódó társadalmi integráció mutatóknak a feltárása, amelyek az objektív és szubjektív térbeli különbségeket, térképzeteket hozzák létre a mai magyar társadalomban.

A tanulmányban a továbbiakban először azt vizsgáljuk, hogy milyen jellemző azonosságok, illetve különbségek alapján írhatók le a vidéki és a városi közösségek. Ennek érdekében egy közösség fontossága indexet alkotunk, majd pedig elemezzük, hogy a társadalmi tőke jellege és mértéke különbözik-e a vidéki, illetve a városi jellegű terekben; ezt egy társadalmi tőke főkomponens segítségével vizsgáljuk. Tovább lépve az adatok 2 A tanulmány az Integrációs és dezintegrációs folyamatok a magyar társadalomban című OTKA kutatás (108836) keretében készült. 
segítségével elemezzük a szubjektív integráció térbeli mintázatait, valamint a szubjektív térképzetek területi és társadalmi jellegzetességeit. Mindezek segítségével arra keressük a választ, hogy a térbeli reprezentációk milyen társadalmi integrációs mutatókhoz (közösség, társadalmi tőke, szubjektív integráció) köthetők, és ezek mennyiben jelentenek valódi térbeli különbségeket.

\section{A VIDÉK ÉS VÁROS KÜLÖNBSÉG HAGYOMÁNYA}

A következő fejezetben áttekintjük, hogy a korábbi kutatások miként értelmezték a közösség térbeli különbségeit. A vidék-város mint az egyik legalapvetőbb térbeli különbség hagyományosan a közösségben illetve annak hiányában reprezentálódik. Ez a képzet a Tönnies (2004) féle vidék-város ellentét percepcióban gyökerezik. Tönnies a 19. századi modernizációs és urbanizációs folyamatokra válaszul fogalmazta meg a közösség és társadalom elméletét, amelynek lényege, hogy közösségi társadalmak organikus módon jönnek létre, míg a modern társadalmak emberi beavatkozás termékei. A Tönnies-i elmélet egyfajta modernizációs folyamatként írja le a változásokat, és amellett érvel, hogy a vidéki tereket inkább jellemzi a tradicionális társadalmi intézmények továbbélése, amelyeket viszont más szerzők gyakran kapcsolnak a közösségek erősségéhez, így például a személyközi bizalom magasabb szintjéhez is (Füzér 2015). A közösséget jellemző integrációs elemek Tönniesnél a vallás, a lokalitás és a rokonsági kapcsolatok. A közösséget a faluközösséggel azonosítja. Ezzel szemben a nagyvárosi tér az elidegenedés tere, ahol a szoros interperszonális kapcsolat, a közösségi integrációs elemek meggyengülnek. A nagyvárossal jelképezett társadalomra az individualizáció, a kapcsolatok lazasága, a politika és közvélemény térnyerése jellemzo, és a fő integrációs elemek az intézmények, a gazdaság és politika. Durkheim társadalmi munkamegosztás elmélete szintén utal, illetve támaszkodik a város és vidék közötti különbségre a mechanikus és organikus szolidaritás ellentétpárban. A premodern társadalmakra, azaz a rurális közösségekre a mechanikus szolidaritás jellemző, melynek lényege az alacsony szintű munkamegosztás, a szoros közösségi kapcsolatokat, az individualizáció alacsony foka, az alacsony számú de szoros és közvetlen kapcsolatok és a kollektív normák ereje. Ezzel szemben a városokkal fémjelzett modern társadalmakra az organikus szolidaritás jellemző, amely fejlettebb munkamegosztást és a specializáció és individualizáció magasabb fokát is jelenti. A városokban élőkre nagyobb számú, de lazább kapcsolatok és az intézmények nagyobb jelentősége jellemző Durkheim szerint is (Durkheim 2001).

Wirth még tovább lép a város-vidék közötti különbség leírásában. A városi és vidéki életmódot egy skála két ellentétes pólusaként határozza meg. A nagyvárosi életet személytelen, heterogén és laza kapcsolatok jellemzik, a családnak, a rokoni kapcsolatoknak a jelentősége csökken, szekularizált, a csoportszolidaritás hiányzik, formalizált szabályok és rendszerek jellemzik. Ezzel szemben a vidéki életmódra a szoros kapcsolat, a család fontossága, vallásosság, a csoportszolidaritás magas foka és a hagyományok fontossága jellemző Wirth szerint (Wirth 1973).

A fentiekben vázolt klasszikus vidék-város ellentétpár ma is él, mind a tudományos-szakértői, mind a laikus diskurzusban, és meghatározó társadalmi gyakorlatokat eredményez. A vidéki közösség pozitív imázsa alapvető motivációs elemként jelenik meg a városból vidékre vándorlás és a vidékturizmus esetében (Bajmócy 2000, Boyle-Halfacree 1998, Csapák 2007, Csurgó 2013, 2014, Csurgó-Légmán 2015, Csurgó-Szatmári 2014, 
Hardi 2002, Jetzkowitz-Schneider-Brunzel 2007, Kovách 2007). A vidék és közösség összekapcsolódása a vidék idilli reprezentációjának egyik alapeleme (Bell 2006, Csurgó-Légmán 2015, Kovách 2007, Short 2006). Számos kutatás bizonyítja, hogy a vidék reprezentációja jellemzően a várossal szemben határozódik meg (Bell 2006, Csurgó 2013, Halfacree 1995, Kovách 2007). A vidék jelenkori imázsában hangsúlyosan van jelen egy értékelő, döntően idealizáló hozzáállás, amely a vidék pozitív jellemzőit hangsúlyozza a város negatív jellegzetességeivel szemben. A vidékreprezentáció hangsúlyos elemei a biztonság, nyugalom, egészséges élet, a természet szépsége, valamint a közösség és hagyományok kitüntetett fontossága (Csurgó 2013).

Az újabb, főként a poszt-strukturalista vidékszociológiai megközelítést alkalmazó kutatások megtörték a vidék-város dichotómia konceptuális hatalmát, és megkérdőjelezték a strukturális különbségek kitüntetett szerepét a vidéki (és városi) társadalom jellegzetességeinek megragadásában. Az újabb kutatások eredményei azt mutatják, hogy a vidéki népesség és a vidéki területek nem szükségszerűen különbözőek vagy fejletlenebbek, mint a városiasként meghatározott területek. A kutatók amellett érvelnek, hogy mind a mezőgazdaság modernizációja és a hozzá kapcsolódó munkaerő-piaci változások, mind a vidéki területek egyre növekvő mértékben fogyasztásközpontú használata (turizmus, természetvédelem, vidékre költözés) azt jelzi, hogy a vidék-város elkülönülő természete nem tartható (Cloke 1997, DuPuis 2006, Frouws 1998, Halfacree 1993, 1995, Kovách 2012, Mormont 1990, Mormont (1987) fogalmazta meg először, hogy nem az a kérdés, mi a vidék, hanem az, hogy a különböző szereplők hogyan értelmezik és érzékelik a vidéket, és ez mit mond el a társadalom szerkezetéről és hatalmi viszonyairól. Mormont vezette be elemzési kategóriaként a ruralitás fogalmát és elemzési eszközként a reprezentációt és diskurzust. Hasonlóképpen érvel Cloke (1997) is, aki szerint a vidék és város közötti különbség lényegében semmivé vált, a vidék mint önálló kategória nem létezik többé, egy társadalmilag létrehozott diszkurzív kategória csupán, amely rendkívül összetett, és ezért nehezen definiálható. Halfacree (2007) pedig arra is kísérletet tesz, hogy a reprezentációk, a mindennapi élet jellegzetességei alapján létrehozza a vidéki tér általános leíró modelljét. A modell három fő elemből épül fel. Az első elem a lokalitás sajátos társadalmi-gazdasági karaktere, amely a relatíve különböző társadalmi és térbeli gyakorlatokat jelenti kapcsolódva a fogyasztási és termelési tevékenységekhez, a második a vidék formális reprezentációja, amit a tervezők és politikusok befolyásolnak, ezek valójában megfeleltethetők az objektív (közigazgatási, fejlesztési) területi kategóriákkal és a hozzá kapcsolódó diskurzussal. A harmadik pedig a mindennapi gyakorlatokat jelenti, ami meglehetősen szubjektív és változatos, a koherencia és töredezettség eltérő szintjeivel jellemezhető, és kisebb vagy nagyobb mértékben befolyásolja a többi kategóriát. A fenti modell is mutatja, hogy az objektív térkategóriák és a hozzá kapcsolódó diskurzusok csak egy elemét jelenthetik a térbeli különbségek leírásának, amit a társadalmi-gazdasági jellegzetességek, a mindennapi gyakorlatok és a hozzá kapcsolódó szubjektív térképzetek egyaránt befolyásolnak.

Fontos magyar sajátosság, hogy bár a vidék-város dichotómia diskurzus Magyarországon is jelen van és a vidék közösséggel azonosított pozitív képzete nálunk is él, a magyar vidékkép ezzel együtt kettős, az idilli mellett van egy meglehetősen kritikai oldala is, amely a vidék problémáira, a társadalmi feszültségekre és az életkörülmények negatív elemeire reflektál (Csurgó 2007, Kovách 2007). A vidékképnek ez az összetettsége azonban nem írja felül a város-vidék dichotómia diskurzus jelenlétét sem (Csurgó 2007, Kovách 2007, Megyesi 2007). A kutatók többsége kiemeli, hogy a diskurzus és reprezentáció szintjén a vidék-város dichotómia tovább él, még 
ha ez a tényleges térbeli-társadalmi kategóriákhoz nem is kapcsolható közvetlenül (Kovács-Vidra-Virág 2013).

A posztstrukturalista vidékszociológiai megközelítés alapján tanulmányunk célja tehát, hogy az adatok segítségével megerősítsük azt az elméletet, hogy a vidék-város dichotómia alapvetően egy diszkurzív kategória, és nem feleltethető meg egy az egyben a közigazgatási területi kategóriáknak. Ennek érdekében azt kívánjuk tesztelni és bizonyítani, hogy a vidék-város elkülönülés, amely leginkább a társadalmi tőke jellegzetességeinek különbségében és a közösség fontosságának eltéréseiben reprezentálódik, nem mutat egyértelmú térbeli mintázatokat, és a szubjektív térérzékelésnek is csak egyik, de nem a legfőbb meghatározója. Leíró elemzésünkben mindezek alapján pedig amellett érvelünk, hogy a térbeli integráció nem ragadható meg a város-vidék ellentétben. Nem célunk sem az integrációs mutatók, sem a térképzeteket létrehozó társadalmi mutatók mélyebb elemzéssel való feltárása. Jelen tanulmány keretei között csupán azt kívánjuk megnézni és leírni, hogy a vidékváros dichotómia diskurzusban megjelenő különbségek igazolhatók-e valós vidéki és városi terek objektív és szubjektív különbségeiben.

\section{A VIDÉK-VÁROS DICHOTÓMIA MÉRÉSE FELÉ: A KÖZÖSSÉG FONTOSSÁGA ÉS A TÁRSADALMI TŐKE}

A vidék város különbség egyik legfontosabb eleme a közösség, mint azt a fentiekből is láttuk. Míg a vidéket a közösséggel, a közösségek fontosságával szokás azonosítani, a város a közösségek széthullásának és az elidegenedésnek a tereként reprezentálódik (Tönnies 2004, Wirth 1973). Az adatbázis³ lehetőségeihez igazodva a közösség fontosságának mérésére egy indexet hoztunk létre. A felmérés során megkérdeztük a válaszadókat, hogy mennyire fontosak számukra a különböző közösségek: (1) család, (2) baráti társaság, (3) munkahely/iskolai közösség, (4) szomszédság, (5) lakóhelyi, helyi közösségi szervezet. A kérdésre adott válaszok alapján hoztuk létre a közösség fontossága indexet. ${ }^{4}$ A közösség fontossága index átlaga: 18,78.

A vidék-város dichotómia a közösségek fontosságán túl a társadalmi tőke jellegzetességeink különbségében reprezentálódik. A továbbiakban bemutatjuk, hogy a társadalmi tőke mérésére az adatbázis adta lehetőségekhez igazodva és a szakirodalomra támaszkodva milyen mérőszámokat alkalmazunk az elemzés során.

A társadalmi tőke mérésére egy főkomponenst hoztunk létre. A főkomponens megalkotása során két szempontot tartottunk szem előtt: a korábbi kutatási eredményeket és a rendelkezésre álló adatok jellegét.

A társadalmi tôke meghatározása során ebben az írásban is a fogalom bourdieu-i hagyományhoz igazodó meghatározását alkalmazzuk (Bourdieu-Angelusz 1997, Megyesi 2014, 2015). A meghatározás alapjának azt a megállapítást tekintjük, hogy a társadalmi tőke hatásait mindenekelőtt egyéni szinten kell értelmezni, csoportszinten ezt csak metaforikusan lehet megtenni. A társadalmi tőke forrása pedig az emberek közötti kapcsolatokban, hálózatokban, közösségekben rejlik (Szreter-Woolcock, 2004:654).

A továbbiakban azt vizsgáljuk, hogy a számunkra releváns korábbi kutatások milyen módon operacionalizálták a társadalmi tóke fogalmát. A társadalmi tôke mérésére számos eljárás létezik, és ahogy a mi esetünkben, úgy más kutatások esetében is megfigyelhető, hogy a szerzőket a rendelkezésre álló adatok jellege legalább annyira befolyásolja az operacionalizálás során, mint a korábbi kutatási eredmények. Az írások jelentős

3 A minta a 18 év feletti magyarországi népességre reprezentatív.

4 A változó 1-5 skálán mérte az adott közösség fontosságát, az indexben pedig összeadtuk az egyes kérdésekre adott válaszokat. 
része a társadalmi tőke hálózati jellegét hangsúlyozva az önálló területnek tekinthető hálózat-elemzés módszerét alkalmazza (Csizmadia 2008: 308). A hálózatkutatás önálló paradigmává vált az elmúlt évtizedekben (Albert-Dávid 2004, Sík 2006, Tardos 1995). Jelen tanulmányban az egyénre, illetve az adott közösségre jellemző társadalmi tőkét az alábbi indikátorokkal mérjük: bizalom, közös értékek, közösség jellemzői, civil és politikai aktivitás, önkéntesség mértéke, együttmúködési készség. E megközelítés Putnam, Fukuyama és Grootaert, valamint Ostrom és munkatársainak (Grootaert-Bastelaer 2001, Ostrom 2011, Putnam-Leonardi-Nanetti 1993) munkáiban követhető nyomon, melyekben hagyományos kérdőíves vizsgálatokkal, illetve statisztikai adatokra támaszkodva vizsgálják nagyobb közösségekben a társadalmi tőke mértékét a fenti indikátorokat mérve.

Bár éppen ezt a megközelítést érte a legtöbb kritika amiatt, hogy olyan indikátorokra építenek, amelyek esetében nem lehet világos határvonalat húzni az okok és okozat között, azaz hogy az adott indikátor a társadalmi tőke mértékét jelzi-e, vagy a társadalmi tőke adott mértékéből következik-e az adott indikátor értéke (például a bűnözés mértéke, vagy a bürokratizálódás tekinthetők ilyen vitatott státusú indikátoroknak), elfogadjuk azt az érvelést, hogy a társadalmi tőke mérésére leginkább a jelzőszámok alkalmasak (Grootaert-Bastelaer 2001: 27-30).

A következő bekezdésekben azt mutatjuk be, hogy a korábban alkalmazott mérési eljárások hogyan illeszthetők az általunk használni kívánt társadalmi tőke főkomponensbe.

A kapcsolathálózati megközelités megkerülhetetlennek látszik a kutatás szempontjából, ezért a válaszadók kapcsolatait leíró változók bekerültek a főkomponensbe.

A bizalom és a megbízhatóság közötti dilemmát illetően Megyesi $(2014,2015)$ korábbi írásaiban amellett érvel, hogy Ostrom és Ahn modellje a leginkább elfogadható, amely a megbízhatóságot előtérbe helyezi a bizalommal szemben, amennyiben a társadalmi tőke jellegét és mértékét szeretnénk leírni. A szerzők szerint a megbízhatóság, amely arra utal, hogy valaki az adott társadalmi struktúrától függetlenül viszonozza a belé vetett bizalmat, megfelelő indikátora a társadalmi tőkének. Ebben a kutatásban azonban kompromisszumot kellett kötnünk: a megbízhatóság nehezen feltárható indikátor, a kérdőíves vizsgálat kérdései az általános bizalom szintjét teszik megragadhatóvá, amely jelen vizsgálat keretei között alkalmas a város-vidék dichotómia társadalmi tőke alapú eltéréseinek vizsgálatához.

A társadalmi részvétel fontos jelzője lehet a társadalmi tôkének, és része a vidék-város dichotómia diskurzusnak is, ismerve és elfogadva az esetleges kritikákat (lásd például Sík 2006, vagy részletesen Megyesi 2014), a különböző közösségekben, szervezetekben és a szavazásokon való részvételt beépítettük a társadalmi tőke főkomponensbe.

A társadalmi tőke főkomponensbe tehát az alábbi változókat vontuk be:

A kapcsolatok jellegét és kiterjedtségét az alábbi változókkal kínjuk megragadni:5

- erős kapcsolatok száma ${ }^{6}$

5 A dolgozatban nem írunk részletesen azokról a változókról, amelyeket a kutatócsoport tagjai közösen hoztak létre.

6 Az erős kapcsolatok száma: akikkel a kérdezett a fontosabb dolgait, problémáit megbeszélte (51-es kérdés), akikkel közös programot csinálhat, eljárhat szórakozni, összejöhet kikapcsolódni, esetleg vendégeskedni, ha van egy kis szabad ideje, illetve akiktől segítséget kaphat. A segédváltozó kialakítása során, ha egy személyt több helyen is említettek, akkor is csak egyszer került be az indexbe. 


\section{- $\quad$ gyenge kapcsolatok száma ${ }^{7}$}

Az erős és gyenge kötések száma azon túl, hogy a társadalmi tőke egyik legfontosabb alkotóeleme, a város-vidék ellentét képzetének is alapeleme. A klasszikus diskurzus szerint a vidékre inkább az erős kötések, míg a városra inkább a gyenge kötések jellemzőek. A mozgósítható gyenge kötések, azaz a kapcsolatok minősége pedig a közösséggel aposztrofált vidékre inkább jellemző, mint az elidegenedett városra a képzetek szerint.

A társadalmi tőke mutatói között fontos helyet foglal el a bizalom. A város-vidék ellentét képzetben a személyközi bizalom inkább vidéki, míg az intézményi bizalom inkább városi jellegzetesség. A bizalom változót a személyközi bizalom mértékét mérő és az intézményi bizalom mértékét mérő változók átlagaiból képzett változóval kívánjuk megragadni.

A részvétel és általában az intézményesített kapcsolatok városi sajátosságként jelennek meg, ahol az egyének az intézményeken keresztül válnak a közösség és társadalom részévé szemben a vidéket jellemző közvetlen, személyközi kapcsolatokkal (Durkheim 2001, Tönnies 2004, Wirth 1973)

A társadalmi részvétel és a helyi, illetve országos ügyekre gyakorolt hatást ${ }^{10}$ a lábjegyzetben található

7 A változó a gyenge kapcsolatok számát méri, azaz erre a kérdésre adott válaszokat: Kérem, mondja meg, hogy személyesen ismer-e ilyen foglalkozású embereket. A „személyesen ismeri” itt azt jelenti, köszönő viszonyban vannak, névről ismerik egymást. Ha valamelyik kérdésre nem válaszolt a kérdezett, missing a változó értéke (36 eset).

8 Általánosságban Ön mit mondana? A legtöbb emberben meg lehet bízni, vagy inkább azt, hogy nem lehetünk elég óvatosak az emberi kapcsolatokban. (0-10 skála, ahol a 10 azt jelenti, hogy a legtöbb ember megbízható).

9 Kérem, mondja meg, hogy Ön személy szerint mennyire bízik a következő intézményekben:

- a magyar Országgyülésben?

- a magyar jogrendszerben?

- a rendörségben?

- a politikusokban?

10 Kérjük, mondja meg, ha az elmúlt egy év során az adott területen részt vett valamilyen egyesület, alapitvány, önkéntes társulás, egyéb hasonló szervezet munkájában, tevékenységében!

Részt vett Ön a ..........?

- Vallási, egyházi szervezet (nem gyülekezet) tevékenységében

- Politikai párt tevékenységében

- Szakszervezet tevékenységében

- Valamilyen egyesület, alapitvány (pl. sportegyesület, környezetvédö szervezet stb.) tevékenységében

- Egyéb, éspedig

- Igen/Nem válaszok száma

- Ha most vasárnap lennének a választások, elmenne-e szavazni?

- Igen: Biztosan, illetve valószínúleg elmenne szavazni,

- Nem: Valószínúleg nem menne el, vagy ha csak a most müködő pártok közül lehet választani, akkor valószínüleg nem menne el, vagy semmiképpen nem menne el szavazni?

Különböző módokon lehet a közügyekben cselekedni, a problémák megoldásáért fellépni. Az elmúlt 12 hónap során előfordult-e, hogy Ön ezek közül a dolgok közül valamelyiket megpróbálta?

- Kapcsolatba lépett politikussal vagy önkormányzati képviselövel.

- Tevékenykedett egy politikai pártban, részt vett a rendezvényein.

- Részt vett más politikai szervezet vagy politikai mozgalom munkájában.

- Viselt vagy kihelyezett politikai jelvényeket, jelképeket.

- Tiltakozó levelet, petíciót írt alá, hagyományos vagy internetes formában.

- Részt vett tüntetésen (demonstráción).

- Szándékosan nem vásárolt, bojkottált bizonyos árucikkeket.

- Pénzt adományozott civil szervezetnek

- elöfordult / nem fordult eló 
kérdésekkel kívánjuk megragadni.

A társadalmi tőkét mérő változó megalkotása során arra törekedtünk, hogy a három dimenzió megközelítőleg egyenlő súllyal jelenjen meg, ezért főkomponenst állítottunk elő azokból. Az alábbi táblázat a társadalmi tőke főkomponenst alkotó, az egyes dimenziók átlagértékeit mutatja:

1. táblázat: A társadalmi tőke fökomponens dimenziói

\begin{tabular}{|l|l|l|}
\hline Dimenzió & aldimenzió/változó & Átlag érték \\
\hline Kapcsolati dimenzió & Erős kötések száma: & 2,42 \\
\hline & Gyenge kötések száma: & 8,40 \\
\hline Kapcsolati index & átlag értéke (az erős kötéseket dupla súllyal számolva) & 33,1 \\
\hline Bizalmi index & átlag értéke & 13,31 \\
\hline Civil részvétel: & & 0,024 \\
\hline Politikai aktivitás: & & 0,74 \\
\hline Részvételi index & értéke & 7,64 \\
\hline
\end{tabular}

2. táblázat. A társadalmi tőke fökomponens alkotó indexeinek súlya

\begin{tabular}{|l|c|}
\hline & Component (1) \\
\hline Szavazási kedv, részvétel szervezetekben, politikai aktivitás index & 0,751 \\
\hline Összevont bizalom index (intézményi + személyközi). & 0,476 \\
\hline Gyenge és erős kötések száma & 0,734 \\
\hline Extrakciós módszer: Főkomponens. & \\
\hline
\end{tabular}

\section{A VÁROS ÉS A VIDÉK KÖZÖTTI KÜLÖNBSÉGEK EMPIRIKUS VIZSGÁLATA}

Az elemzés során az alábbi fő változókat használjuk.

\section{3. táblázat. A vizsgált változók alapeloszlása}

\begin{tabular}{|l|l|}
\hline Közösségek fontossága index & $\mathrm{N}=2249$ \\
\hline Átlag: & 18,78 \\
\hline Szórás: & 3,50 \\
\hline Közigazgatási beosztás szerint & $\mathrm{N}=3553$ \\
\hline Városi lakosok aránya (\%) & 70 \\
\hline Községekben lakók aránya (\%) & 30 \\
\hline Szubjektív önbesorolás szerint & $\mathrm{N}=3541$ \\
\hline Városias lakókörnyezetben élők arány (\%)a & 47,3 \\
\hline Falusias lakókörnyezetben élők aránya (\%) & 52,7 \\
\hline Településméret (lakosságszám szerint) & $\mathrm{N}=3553$ \\
\hline Átlag: & 43804,56 \\
\hline Szórás: & 52233,4 \\
\hline
\end{tabular}




\section{VÁROS-VIDÉK DICHOTÓMIA}

Elemzésünk központi kérdése a vidék-város dichotómia megragadására leginkább két változó, (1) a közigazgatási besorolás és (2) a szubjektív lakóhelyképzet (lakókörnyezet önbesorolása) ad lehetőséget.

4. táblázat. A közigazgatási és szubjektiv lakóhely besorolás közötti összefüggés

\begin{tabular}{|l|l|l|l|}
\hline \multirow{2}{*}{$N=3541$} & \multicolumn{2}{l|}{ közigazgatási besorolás } \\
\cline { 3 - 4 } & város & vidék \\
\hline \multirow{2}{*}{ Szubjektív besorolás } & Városias & $67,2 \%$ & $0,9 \%$ \\
\cline { 2 - 4 } & Vidékies & $32,8 \%$ & $99,1 \%$ \\
\hline
\end{tabular}

Sig=0,000, azaz szignifikáns a két változó közötti kapcsolat.

Adataink azt mutatják, hogy a közigazgatási vidék-város besorolás és a szubjektív lakóhelyképzet, azaz, hogy a kérdezett vidékiesnek vagy városiasnak érzi-e a települést, ahol él, nem esik egybe. Jelentős eltérés a város esetében található, a közigazgatásilag városi rangú településen élők 32,8\%-a vidékiesnek észleli a települést, ahol él, míg a vidéki besorolású (község, nagyközség) települések lakói konzisztens módon 99,1\%-ban vidékiesnek érzékelik a lakóhelyüket, és mindössze 0,9\% érzi inkább városiasnak azt a települést, ahol él.

Adataink tehát azt jelzik, hogy lényeges különbség van a szubjektív lakóhelyképzetek és a közigazgatási besorolás között. A tanulmány további részében azt vizsgáljuk, hogy a közigazgatási besorolás és a szubjektív lakóhelyképzetek milyen összefüggést mutatnak a város-vidék dichotómiát leíró, a fentiekben bemutatott mutatókkal.

Először azt vizsgáltuk meg, hogy a lakhely város-vidék közigazgatási besorolása alapján különbözik-e az egyének társadalmi tőkéje, illetve a közösség fontossága:

\section{5. táblázat.}

A társadalmi töke fökomponens, illetve a lakóhely közigazgatási és szubjektiv besorolása közötti összefüggés

\begin{tabular}{|l|l|l|l|}
\hline Közigazgatási besorolás & & $\begin{array}{l}\text { Társadalmi tőke főkomponens } \\
(\mathrm{N}=3070)\end{array}$ & $\begin{array}{l}\text { Közösség szerepe az egyén életében } \\
(\mathrm{N}=2251)^{*}\end{array}$ \\
\hline város & Átlag & 0,0083126 & 18,6115 \\
\hline vidék & Átlag & $-0,02000590$ & 19,1673 \\
\hline Összesen & Átlag & $-0,000000$ & 18,7842 \\
\hline & Szig & 0,4754 & 0,000 \\
\hline Szubjektív besorolás & & $\begin{array}{l}\text { Társadalmi tőke főkomponens } \\
(\mathrm{N}=3062)^{*}\end{array}$ & $\begin{array}{l}\text { Közösség szerepe az egyén életében } \\
(\mathrm{N}=2244)^{*}\end{array}$ \\
\hline Városias & Átlag & 0,04289 & 18,5533 \\
\hline Vidékies & Átlag & $-0,040700$ & 18,9922 \\
\hline Összesen & Átlag & $-0,004903$ & 18,7875 \\
\hline & Szig & 0,0214 & 0,003 \\
\hline
\end{tabular}

*szignifikáns összefüggés

A fentiek alapján a lakóhely közigazgatási besorolásától nem függ az egyének társadalmi tőkéje, viszont a közösség a községek lakói számára fontosabb (még ha kis mértékben is), mint a városi lakosok számára.

Amennyiben azt vizsgáljuk, hogy mennyire különbözik a két vizsgált változó aszerint, hogy a válaszolók milyennek érzékelik a lakókörnyezetüket (városiasnak avagy falusiasnak), azt találtuk, hogy a lakóhely szubjektív 
besorolása és a társadalmi tőke között, ha gyengén is, de van kapcsolat. A lakóhely városiasnak való érzékelése pozitívan, míg a vidékies lakóhely szubjektív besorolás negatívan hat a társadalmi tőke mértékére. A közigazgatási besorolás esetében tapasztaltakhoz hasonlóan a közösséget a vidékies lakóhelyen élők tartják fontosabbnak.

A település lakosságszámának és a társadalmi tőke, illetve a közösség fontosságának kapcsolat közötti korrelációt szintén vizsgáltuk, és gyenge összefüggést találtunk a társadalmi tőke mértéke és a településméret között. Érdekes, hogy itt megfordul az összefüggés, azaz azt látjuk, hogy a település lakosságszámának növekedésével nő a társadalmi tőke mértéke, viszont a településméret és a közösségek fontossága között nincs összefüggés.

Mivel a társadalmi tôke és a település jellege között nem mutatható ki összefüggés, vagy csak nagyon gyenge, és a hagyományos diskurzussal ellentmondó, illetve a létező irodalom alapján feltételezhető, hogy a társadalmi tőke egyes dimenziói eltérő értékűek lehetnek a városi és a vidéki terekben, ezért külön-külön is vizsgáltuk a társadalmi tőke egyes dimenziói és a település közigazgatási besorolása illetve a szubjektív lakhelyképzet közötti összefüggést.

6. táblázat.

A társadalmi tőke egyes dimenziói és a lakóhely közigazgatási besorolása közötti összefüggés; az egyes értékek átlaga

\begin{tabular}{|l|l|l|l|l|l|}
\hline Közigazgatási besorolás & város & vidék & Összesen & $(\mathrm{N})$ & Szig. \\
\hline személyközi bizalom* & 4,87 & 4,47 & 4,75 & 3542 & 0,000 \\
\hline intézményi bizalom* & 4,2032 & 3,8552 & 4,1002 & 3349 & 0,000 \\
\hline gyenge kapcsolatok száma* & 8,1522 & 8,9917 & 8,4024 & 3517 & 0,000 \\
\hline erős kapcsolatok száma & 2,4586 & 2,3442 & 2,4243 & 3553 & 0,052 \\
\hline mozgósítható gyenge kapcsolatok aránya* & 0,61 & 0,5551 & 0,5935 & 3423 & 0,000 \\
\hline szervezeti tagság & 0,0221 & 0,0277 & 0,0238 & 3539 & 0,078 \\
\hline részvételi & 1,9529 & 1,9339 & 1,9473 & 3248 & 0,681 \\
\hline Közvetlen részvétel* & 0,2162 & 0,1460 & 0,1952 & 3533 & 0,000 \\
\hline Tradicionális részvétel* & 0,0636 & 0,1296 & 0,0836 & 3536 & 0,000 \\
\hline
\end{tabular}

*szignifikáns összefüggés

A társadalmi tőke legtöbb dimenziójában van különbség a település kategóriák között (5. táblázat). Az látható, hogy személyközi bizalom, az intézményi bizalom, a gyenge kapcsolatok száma és a mozgósítható gyenge kapcsolatok aránya szignifikánsan eltér a városi és a vidéki területeken. Mind az általános, személyközi bizalom, mind az intézményi bizalom index alapján az látszik, hogy a vidékiek bizalmatlanabbak, mint a városban élők. Az intézményi bizalom a korábbi kutatások szerint is városias tulajdonság. A gyenge kötések száma a vidéken élők esetében szignifikánsan magasabb, míg az erős kötések száma között nincs különbség a vidéken és városban élők között, így az adatok a szorosabb kapcsolatok, a közösségek zártsága és interperszonális kapcsolatokra építő vidék imázst sem tudták igazolni. A hagyományos vidék-város diskurzus alapján feltételezhető ugyan, hogy a gyenge kapcsolatok száma magasabb vidéken, és alacsonyabb a városokban, ugyanakkor, a mozgósítható gyenge kapcsolatok aránya alacsonyabb vidéken, amely szintén ellentmond az elidegenedett város és a szorosabb

i Választási, direkt és tradicionális részvétel. 
kapcsolatokra épülő vidék tézisnek. A részvétel és szervezeti tagság esetében pedig nem mutatnak különbséget az adatok a közigazgatási besorolás szerint vidéken és városban élők között, azonban ha a politikai véleménynyilvánítást tovább bontjuk, közvetlen és tradicionális részvételre, akkor szignifikáns különbségeket találunk, ráadásul azok az előzetes várakozásoknak megfelelő mintába rendeződnek: a tradicionálisnak tekintett részvételi módok gyakoribbak a községekben, mint a városokban. Összességében azonban az adatok inkább ellentmondanak az elidegenedett város képzetének és a város-vidék dichotómia hagyományos leírásainak.

A következő táblázatban a társadalmi tôke egyes dimenziói és a település szubjektív jellege közötti öszszefüggést elemezzük.

7. táblázat.

A társadalmi tőke index egyes dimenziói és a lakóhely szubjektív besorolása közötti összefüggés: az egyes értékek átlaga

\begin{tabular}{|l|c|c|c|c|c|}
\hline Szubjektív besorolás & Városias & Vidékies & Összesen & $(\mathrm{N})$ & Szig. \\
\hline személyközi bizalom* & 4,96 & 4,57 & 4,76 & 3530 & 0,000 \\
\hline intézményi bizalom* & 4,3802 & 3,8494 & 4,1015 & 3339 & 0,000 \\
\hline gyenge kapcsolatok száma* & 7,9954 & 8,774 & 8,4057 & 3505 & 0,000 \\
\hline erős kapcsolatok száma* & 2,5675 & 2,2955 & 2,4241 & 3541 & 0,000 \\
\hline mozgósítható gyenge kapcsolatok aránya & 0,6057 & 0,5824 & 0,5934 & 3411 & 0,054 \\
\hline szervezeti tagság & 0,0212 & 0,026 & 0,0237 & 3528 & 0,103 \\
\hline részvételii & 1,9711 & 1,9229 & 1,946 & 3237 & 0,255 \\
\hline Közvetlen részvétel* & 0,2404 & 0,1535 & 0,1946 & 3521 & 0,000 \\
\hline Tradicionális részvétel* & 0,0561 & 0,1078 & 0,0833 & 3524 & 0,000 \\
\hline
\end{tabular}

*szignifikáns összefüggés

A szubjektív térképzetek esetében szintén találunk eltéréseket a városinak illetve a vidékinek érzékelt tér között (6. táblázat). A közigazgatási város-vidék besorolásnál tapasztalhatókhoz hasonlóan az látható mind a személyközi bizalom, mind az intézményi bizalmi index alapján, hogy a vidékiek bizalmatlanabbak, mint a városban élők, ami ellentmond az elidegenedett város képzetének. A gyenge kötések száma a vidékiesnek érzékelt lakhelyen élők esetében szignifikánsan magasabb, míg az erős kötések száma alacsonyabb, ami ellentmond a klasszikus vidék-város ellenét diskurzusnak. A szubjektív lakóhelyképzetek és a mozgósítható gyenge kötések aránya, ellentétben a közigazgatási besorolás szerinti lakóhellyel, nem mutat szignifikáns kapcsolatot. Ugyanígy a részvétel és szervezeti tagság sem, ahogy az előbb sem, azonban itt is azt látjuk, hogy a (politikai) részvételt dimenzióira bontva, a tradicionális és a közvetlen részvételi formák elterjedtsége már szignifikánsan különbözik a városiasként illetve a vidékiként érzékelt térben. A korábbi táblázat mintái ismétlődnek, enyhén megerősödve: a vidékies terekben a tradicionális részvételi formák jelenléte gyakoribb, míg a városias terekben a közvetlen részvételi formák gyakorlása a valószínűbb; bár mindkettő igen csekély mértékü.

ii Választási, direkt és tradicionális részvétel. 


\section{ELIDEGENEDÉS ÉS A LAKÓHELY SZUBJEKTíV ÉRZÉKELÉSE}

A társadalmi tőke dimenzióit és a közösségek fontosságát elemezve nem sikerült igazolnunk, hogy a városi és vidéki terek között olyasféle különbségek lennének, mint amelyet az irodalom feltételez: a különbségek esetlegesek, és nem rendeződnek mintázatba, ezért további változókat vontunk a vizsgálatba. A továbbiakban elemezzük, hogy miként érzékelik a környezetüket a válaszolók, illetve részletesebben elemezzük a társadalmi részvétel formáit. Először a lakóhely közigazgatási besorolása alapján vizsgáljuk a városban, illetve a vidéken élők közötti különbségeket, majd a lakóhely szubjektív besorolását vizsgáljuk.

A vidék és város dichotómia képzetek megragadására adatbázisunk a társadalmi tóke fentebb bemutatott dimenzióin túl további lehetőségeket is kínál. A város a vidék-város dichotómia diskurzusban az elidegenedés tereként jelenik meg, míg a vidék ennek az ellenpólusát jeleníti meg. Ennek a képzetnek a tesztelésére az adatbázis a következő kérdések segítségével kínál lehetőséget.

Az elidegenedést a következő válaszok alapján létrehozott érzékelt társadalmi kirekesztettség index mutatja:

- Úgy érzem, kitaszít a társadalom.

- Az élet olyan bonyolulttá vált, hogy alig találom a helyemet.

- Úgy érzem, hogy az emberek, akikkel találkozom, nem ismerik fel az értékét annak, amit csinálok.

- Néhány ember lenéz engem a munkám miatt, vagy azért, mert nem dolgozom.

Ennek az ellenpólusát pedig mérhetjük a szubjektív társadalmi fontosság mutatóval:

- Összességében mennyire tartja önmagát a társadalom fontos, hasznos tagjának? Kérem, értékelje 0-tól 10-ig, ahol 0=egyáltalán nem fontos, hasznos, 10=kifejezetten fontos, hasznos.

Továbbá az adatbázis a lakóhely szubjektív értékelésére vonatkozóan is tartalmaz információkat.

- Kérem, válaszoljon, hogy az alábbi tulajdonságok, jelenségek Ön szerint mennyire jellemzőek arra a környékre, ahol Ön lakik! Kérem, osztályozza 1-töl 5-ig, ahol 1-es jelentése, hogy egyáltalán nem jellemző, az 5-ös jelentése pedig, hogy nagyon jellemző.

- Mindenki ismer mindenkit

- Szomszédolás

- Irigykedés, versengés

- Együttmüködés, egymás segítése

- Nyitottság, elfogadás

- Rosszindulat, ellenségeskedés

- Kulturális hagyományok megtartása, ápolása

A klasszikus város-vidék dichotómia diskurzus szerint a vidéki idill képzetéhez tartozik, hogy mindenki ismer mindenkit, a szomszédolás, az együttmúködés, a nyitottság, elfogadás, valamint a hagyományok ápolása. Ezzel szemben az elidegenedett várost a versengés és ellenségeskedés jellemzi, valamint a fentiekben felsoroltak hiánya. Emellett a vidék közösség alapú idilljéhez hozzátartozik, hogy a vidéken élők a társadalom integráns részének érzékeljék önmagukat, míg az elidegenedett város képzetéhez a társadalmi dezintegráció kapcsolódik, aminek megfelelő mérőeszközét jelenti adatbázisunkban a szubjektív társadalmi fontosság és az érzékelt 
társadalmi kirekesztettség mutatók. A fenti kérdések alapján tesztelhető, hogy a közigazgatási kategóriák és a szubjektív lakóhelyképzet kategóriák mennyire kapcsolódnak a klasszikus vidék-város imázshoz. Az alábbiakban ennek elemzését végezzük el.

8. táblázat.

A környék jellemzői és a lakóhely közigazgatási besorolása közötti összefüggés: az egyes értékek átlaga

\begin{tabular}{|l|c|c|c|c|c|}
\hline Közigazgatási besorolás & város & vidék & Összesen & $(\mathrm{N})$ & Szig. \\
\hline $\begin{array}{l}\text { A környékre jellemző, hogy mindenki ismer min- } \\
\text { denkit* }\end{array}$ & 3.22 & 4,17 & 3,51 & 3525 & 0,000 \\
\hline A környékre jellemző a szomszédolás* & 2,54 & 3,06 & 2,70 & 3528 & 0,000 \\
\hline A környékre jellemző az irigykedés, versengés* & 2,31 & 2,65 & 2,42 & 3205 & 0,000 \\
\hline $\begin{array}{l}\text { A környékre jellemző az együttmúködés, egymás } \\
\text { segítése * }\end{array}$ & 2,96 & 3,20 & 3,04 & 3377 & 0,000 \\
\hline A környékre jellemző a nyitottság, elfogadás* & 2,96 & 3,24 & 3,04 & 3400 & 0,000 \\
\hline $\begin{array}{l}\text { A környékre jellemző a rosszindulat, ellenséges- } \\
\text { kedés* }\end{array}$ & 2,29 & 2,48 & 2,35 & 3222 & 0,000 \\
\hline $\begin{array}{l}\text { A környékre jellemző a kulturális hagyományok } \\
\text { megtartása, ápolása* }\end{array}$ & 2,28 & 2,94 & 2,48 & 3237 & 0,000 \\
\hline Szubjektív társadalmi fontosság & 6,56 & 6,42 & 6,52 & 3470 & 0,999 \\
\hline Érzékelt társadalmi kirekesztettség* & 4,01 & 5,05 & 4,31 & 3299 & 0,000 \\
\hline
\end{tabular}

*szignifikáns összefüggés

A közigazgatási besorolás szerint vidéken élők szerint a lakóhelyükre a vidék pozitív imázsához tartozó jellegzetességek, mint a mindenki ismer mindenkit, a szomszédolás, a nyitottság, elfogadás és a kulturális hagyományok ápolása sokkal inkább jellemző, mint a közigazgatásilag városi településeken élők szerint. Ez alátámasztani látszik a klasszikus diskurzusban megjelenő vidékimázst. Ugyanakkor a közigazgatásilag vidéken élők tartják inkább jellemzőnek a versengést és ellenségeskedést is, ami részben ellentmondani látszik a hagyományos vidék-város képzeteknek, bár ezen elemek még tekinthetők a közösség zártáságának negatív hatásainak is. Ugyanakkor, ami még ennél is lényegesebb, az elidegenedés legfőbb mutatója az érzékelt társadalmi kirekesztettsége a várttal ellentétben nem a városiakra, hanem sokkal inkább a vidékiekre jellemző, ami teljes mértékben ellentmond a város-vidék szembenálló imázsával. A szubjektív társadalmi fontosság mutató és a közigazgatási lakóhely besorolás között pedig nincs szignifikáns kapcsolat (7. táblázat).

\section{9. táblázat.}

A környék jellemzői és a lakóhely szubjektiv besorolása közötti összefüggés: az egyes értékek átlaga

\begin{tabular}{|l|c|c|c|c|c|}
\hline Szubjektív besorolás & városias & vidékies & Összesen & $(\mathrm{N})$ & Szig. \\
\hline A környékre jellemző, hogy mindenki ismer mindenkit* & 2,95 & 4,00 & 3,51 & 3513 & 0,000 \\
\hline A környékre jellemző a szomszédolás * & 2,37 & 2,99 & 2,70 & 3516 & 0,000 \\
\hline A környékre jellemző az irigykedés, versengés* & 2,22 & 2,58 & 2,42 & 3194 & 0,000 \\
\hline A környékre jellemző az együttmúködés, egymás segítése * & 2,85 & 3,19 & 3,04 & 3367 & 0,000 \\
\hline A környékre jellemző a nyitottság, elfogadás* & 2,85 & 3,22 & 3,04 & 3389 & 0,000 \\
\hline A környékre jellemző a rosszindulat, ellenségeskedés* & 2,25 & 2,43 & 2,35 & 3211 & 0,000 \\
\hline $\begin{array}{l}\text { A környékre jellemző a kulturális hagyományok megtartá- } \\
\text { sa, ápolása* }\end{array}$ & 2,19 & 2,74 & 2,48 & 3228 & 0,000 \\
\hline Szubjektív társadalmi fontosság* & 6,65 & 6,39 & 6,52 & 3458 & 0,000 \\
\hline Érzékelt társadalmi kirekesztettség* & 3,76 & 4,82 & 4,31 & 3288 & 0,000 \\
\hline
\end{tabular}




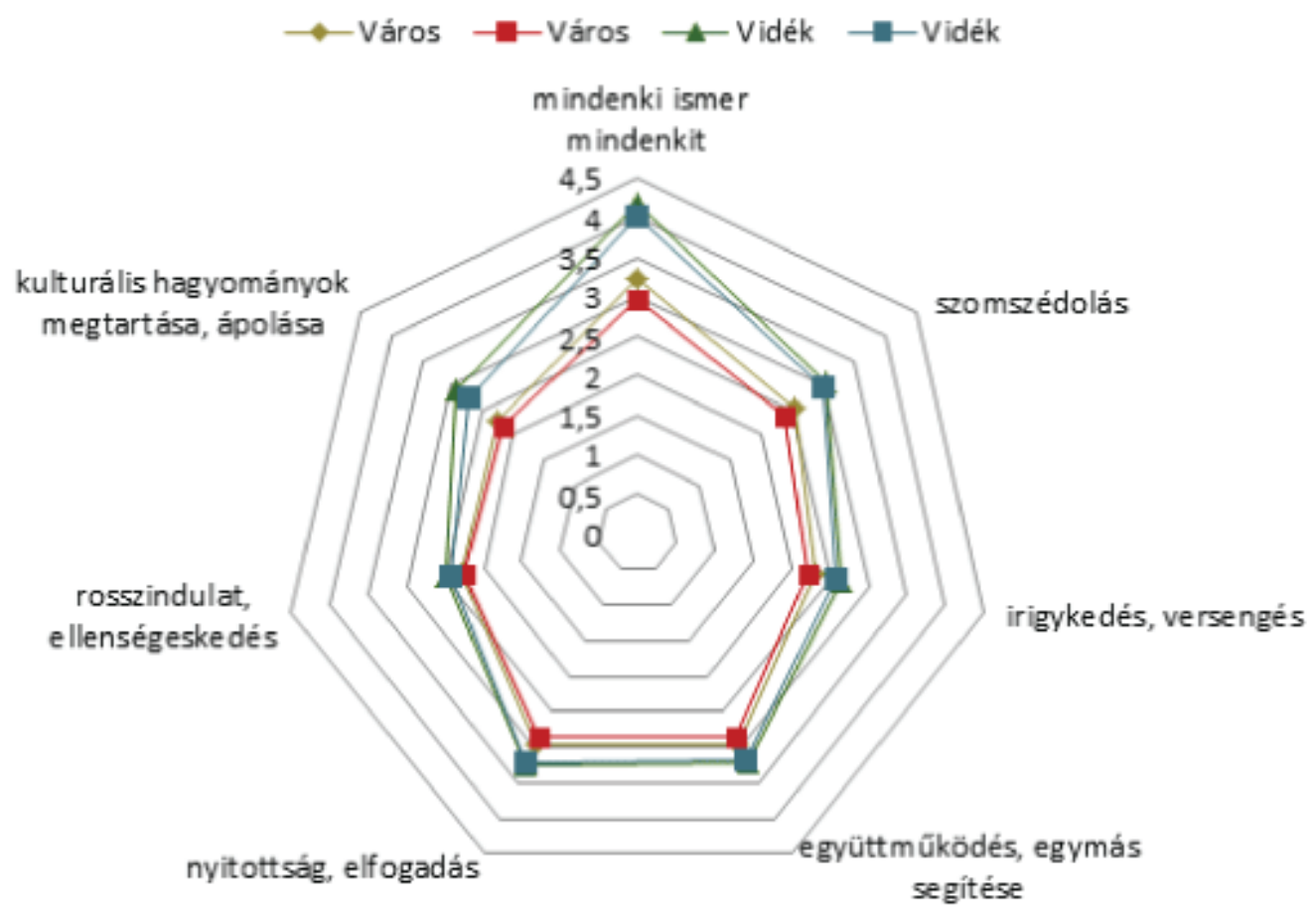

A lakóhely szubjektív besorolása és a lakóhely percepció között a közigazgatási besorolással egybecsengő eredményeket kapunk. A vidékies lakóhely jellemzőjeként jelennek meg az olyan pozitív tulajdonságok, mint hogy mindenki ismer mindenkit, a szomszédolás, a nyitottság, az együttmúködés, a hagyományok ápolása, amelyek kevésbé jellemzik a városias lakóhelyen élők lakókörnyezetét. Ugyanakkor az olyan negatív tulajdonságok, mint az irigykedés vagy rosszindulat is inkább a vidékies lakóhellyel rendelkezők lakóhelyére jellemzőek. Ugyanakkor az elidegenedett város képzete a szubjektív lakóhely besorolás szintjén sem igazolható az adatokkal. Az érzékelt társadalmi kirekesztettség a városias lakóhellyel rendelkezők esetében alacsonyabb, a szubjektív társadalmi fontosság pedig magasabb. Ezzel együtt a vidékies lakóhelyen élők érzékelt társadalmi kirekesztettsége magasabb, a szubjektív társadalmi fontosság pedig alacsonyabb.

Az adataink azt mutatják, hogy a vidék pozitív imázsa és a vidéki lakóhely objektív és szubjektív besorolása között egyaránt szignifikáns kapcsolat van, ugyanakkor a város negatív képzete nem jelenik meg, nem hozható összefüggésbe egyik település besorolással sem. A fentiek alapján úgy tűnik, hogy adataink a pozitiv vidékképzetek és emellett a kirekesztettség érzés - azaz a kitaszítottság, lenézettség, meg nem értettség és bizonytalanság érzés - együttes jelenlétét mutatják a vidéken élők esetében, ami a magyar vidék kettős képzetét tünik alátámasztani.

Kiemelendő továbbá, hogy az objektív és szubjektív lakóhelybesorolás között nincs lényeges eltérés és a lakóhellyel kapcsolatos percepciókban. A rendelkezésre álló adatok alapján úgy tűnik, a saját lakóhely szubjektív észlelése, azaz a saját lakóhely reprezentációja sem igazolja a vidék-város klasszikus dichotómiát, és a lakóhely vidékiesként való észleléséhez nem kapcsolódnak erőteljesebben a vidék imázs elemek, mint az objektiv településkategóriákhoz. Annak megértésére, hogy a lakóhely percepciók milyen társadalmi mutatókkal vannak kapcsolatban, és legfóképpen, hogy mi lehet az oka, hogy a városi rangú településen élők egy része vidékiesnek 
érzi a lakóhelyét, további vizsgálatok szükségesek, amelyek azonban jelen tanulmány keretein túlmutatnak.

A lakóhely objektív és szubjektív besorolása között tehát nincs lényeges különbség a lakóhely percepciók és az érzékelt társadalmi kirekesztettség és fontosság vonatkozásában. A város-vidék dichotómia diszkurzív elemei sem az objektív, sem a szubjektív város-vidék lakóhelykülönbséggel nem igazolhatók.

\section{KÖVETKEZTETÉSEK}

Tanulmányunkban az Integrációs és dezintegrációs folyamatok a magyar társadalomban című OTKA kutatás adatbázisa segítségével készítettünk leíró elemzést a területi integráció egyik dimenziójáról, nevezetesen, hogy a városi és vidéki közösségek, egyéni kapcsolatok, bizalom közötti feltételezett különbségek igazolhatók-e egy empirikus adatfelvétel segítségével. Az adatbázis adta lehetőségek függvényében kiemelten vizsgáltuk a területi integráció társadalmi tőke fogalom segítségével leírható aspektusait. Az eredményeik egy része erre a kérdésre kíván válaszolni. Emellett a dolgozatban vizsgáltuk, hogy a település közigazgatási besorolása, valamint a helyben lakók szubjektív lakóhelyképzete között milyen összefüggés van.

Az elemzéseink alapján kijelenthető, hogy bár a város-vidék dichotómia a diskurzusokban erőteljesen jelen van, az nem kapcsolható egyértelműen sem a szubjektív lakóhelyképzet, sem pedig a közigazgatási lakóhely kategóriák valamelyikéhez. A társadalmi tőkét mérő változónk, amelyet egy viszonylag elterjedt attribútum alapú megközelítést alkalmazva hoztunk létre, nem mutat egyértelmú összefüggést sem a város-vidék közigazgatási besorolás, sem a városias, vidékies besorolást tekintve, ugyanakkor a településmérettel növekszik az egyének társadalmi tókéje, ami részben ellentmond a bemutatott szakirodalom alapján felállított hipotézisünknek.

A korábbi kutatások alapján azt is feltételeztük, hogy a vidék-város dichotómia diskurzus a közösség fontosságában és a társadalmi tôke jellegzetességeiben ragadható meg, ezért a társadalmi tőke fôkomponenst alkotó dimenziókat is részletesen elemeztük. Ennek az elemzésnek két fontos eredménye született: egyrészt azt láthattuk, hogy a társadalmi tőke főkomponensbe bevont mutatóknak egy része a városokban magasabb, például a bizalmi index, vagy az erős kötések száma, más része pedig a községekben, vidékies lakóhelyeken, például a gyenge kötések száma. Eredményeink egy része megfelel a vidéket a közösségek lakhelyének láttató idilli vidékképet sugalló irodalmi adatokkal, egy része azonban ennek ellentmond.

A másik fontos eredmény, hogy a város és a vidék jellemzői között nincsenek lényeges különbségek a szubjektív lakóhelyképzet, illetve a közigazgatási vidék-város besorolás esetében. A lakóhely reprezentáció és a közigazgatási besorolás a vizsgált társadalmi integráció és lakóhely percepció mutatókban nagyon hasonló eredményeket mutat. A vidék-város dichotómia képzetének (Tönnies 2004, Wirth 1973) elemei nem köthetők sem a szubjektív, sem az objektív lakóhely besoroláshoz.

A klasszikus diszkurzív elemek, mint a vidék közösségképzete valamivel hangsúlyosabban a szubjektív lakóhely besorolás esetében jelenik meg, de a közigazgatásilag vidéki lakóhelyen élőknél is megfigyelhető, míg az elidegenedett város képe nem igazolható. Ezek az eredmények alátámasztják kiinduló hipotézisünket, amely szerint a hagyományos vidék-város szembeállítás nem igazolható a lakóhely besorolás alapján.

Fontos a létező szakirodalmi anyagokkal egybevágó eredményünk, hogy bizonyos imázselemek erőteljes 
jelenléte ellenére a vidéken élők társadalmi kirekesztettség észlelése magasabb, míg a társadalmi hasznosság észlelése alacsonyabb, mint a városban élőké; ez a szubjektív lakóhelyképzet szerinti besorolás esetén és a közigazgatási besorolás esetén is fennálló szignifikáns különbség.

Elemzésünk alapján a magyar vidékkép kettős karaktere látszik ismét igazolódni (Csurgó 2007, Kovách 2007, Megyesi 2007). Jelen vannak a vidékkel kapcsolatos pozitív imázs elemek, de inkább csak részleteikben; ezeket a vidékre jellemzőnek érzett társadalmi problémák és a társadalmi dezintegráció érzés felülírja.

Összességében azt látjuk tehát, hogy a poszt-strukturalista iskola tézise igazolható. A térreprezentáció és a térbeli elkülönülés összetett jelenség, amely nem kapcsolható a közösség egy-egy jellegzetes tulajdonságához. A vidék-város különbségek a két tértípus reprezentációjában ragadhatók meg, és nem kapcsolhatók konkrét térkategóriákhoz. A város és a vidék közötti különbségek leírásakor az imázs, a konkrét szocio-ökonómiai helyzet és a mindennapi gyakorlatok (Halfacree 2007) az iránymutatók. Érdemes tehát finomabb elemzések révén feltárni a különbségeket, például a különböző térség-, illetve vidéktípusok (Kovács 2005) és a vizsgált változók közötti összefüggések elemzése révén. 


\section{HIVATKOZÁSOK}

Albert F. - Dávid B. (2004) Magyarországon tanuló külföldi diákok kapcsolathálózati jellemzői. Szociológiai Szemle, (3) 81-91.

Bajmócy P. (2000) A „vidéki ” szuburbanizáció Magyarországon, Pécs példáján. Tér és Társadalom, 14(2-3), 323-330.

Bell, D. (2006) Variations on the rural idyll. In Cloke, P. - Marsden, T. - Mooney, P. (szerk.) Handbook of Rural Studies. SAGE, 149-160.

Bourdieu, P. - Angelusz R. (1997) Gazdasági tőke, kulturális tőke, társadalmi tőke. In A társadalmi rétegződés komponensei. Válogatott tanulmányok. Budapest: Új Mandátum, 156-177.

Boyle, P. - Halfacree, K. (szerk.) (1998) Migration into Rural Areas: Theories and Issues (1 edition). Chichester, UK - New York: Wiley.

Cloke, P. (1997) Country backwater to virtual village? Rural studies and "the cultural turn." Journal of Rural Studies, 13(4), $367-375$. https://doi.org/10.1016/S0743-0167(97)00053-3.

Csapák A. (2007) Az átalakuló Nagykovácsi. Tér és Társadalom, 21(2), 109-116.

Csizmadia Z. (2008) Kapcsolathálózatok és társadalmi „tőkék”. In Némedi D. (szerk.) Modern szociológiai paradigmák. Budapest: Napvilág Kiadó, 265-321.

Csurgó B. (2007) Képek és képzetek a mai magyar vidékről. In Kovách I. (szerk.) Vidékiek és városiak. A tudás- és imázshasználat hatásai a vidéki Magyarországon. L’Harmattan - MTA PTI, 45-67.

Csurgó B. (2013) Vidéken lakni és vidéken élni: A városból vidékre költözők hatása a vidék átalakulására. Budapest: Argumentum MTA TK Szociológiai Intézet.

Csurgó B. (2014) A vidék nosztalgiája: kulturális örökség, turizmus- és közösségszervezés három észak-alföldi kistérségben. Socio.hu, 4(2), 1-20. https://doi.org/10.18030/SOCIO.HU.2014.2.1.

Csurgó B. - Légmán A. (2015) Lokális közösség, megtartó közösség. Socio.hu, 5(4). 50-66. https://doi.org/10.18030/socio.hu.2015.4.50

Csurgó B. - Szatmári A. (2014) Vidéki kultúra, helyi közösség és lokális identitás. A kulturális örökség szerepe a lokális identitásépítésben és a helyi közösségfejlesztésben Hajdúdorogon és Hajdúhadházon. Metszetek, 3(3), 33-51.

DuPuis, M. (2006) Landscapes of desires? In Cloke, P. - Marsden, T. - Mooney, P. (eds.), Handbook of Rural Studies. SAGE, 124-132.

Durkheim, É. (2001) A társadalmi munkamegosztásról. (ford. Csákó M.) Budapest: Osiris.

Frouws, J. (1998) The Contested Redefinition of the Countryside. An Analysis of Rural Discourses in The Netherlands. Sociologia Ruralis. 38(1). 54-68. https://doi.org/10.1111/1467-9523.00063.

Füzér K. (2015) A bizalom társadalomelmélete és a társadalmi tőke szociológiaelmélete. Századvég, 20(78), 5-16.

Grootaert, C. - Bastelaer, van, T. (2001) Understanding and Measuring Social Capital. Washington: World Bank, 24, 31.

Halfacree, K. (1993) Locality and social representation: Space, discourse and alternative definitions of the rural. Journal of Rural Studies. 9(1), 23-37. https://doi.org/10.1016/0743-0167(93)90003-3.

Halfacree, K. (1995) Talking about rurality: Social representations of the rural as expressed by residents of six English parishes. Journal of Rural Studies, 11(1), 1-20. https://doi.org/10.1016/0743-0167(94)00039-C.

Halfacree, K. (2007) Trial by space for a "radical rural": Introducing alternative localities, representations and lives. Journal of Rural Studies, 23(2), 125-141. https://doi.org/10.1016/j.jrurstud.2006.10.002.

Hardi, T. (2002) Szuburbanizációs jelenségek Győr környékén. Tér és Társadalom, 16(3), 57-83.

Jetzkowitz, J. - Schneider, J. - Brunzel, S. (2007) Suburbanisation, Mobility and the "Good Life in the Country": A Lifestyle Approach to the Sociology of Urban Sprawl in Germany. Sociologia Ruralis, 47(2), 148-171.

https://doi.org/10.1111/j.1467-9523.2007.00431.x.

Kovách I. (2007) A múlt és jelen vidékképe. Bevezetés. In I. Kovách (szerk.) Vidék- és falukép a változó időben. Budapest: Argumentum, $7-11$.

Kovách I. (2012) A vidék az ezredfordulón. Budapest: Argumentum.

Kovács É. J. - Vidra Zs. - Virág T. (2013) Kint és bent: Lokalitás és etnicitás a peremvidékeken. Budapest: L’Harmattan.

Kovács K. (2005) Polarizálódás és falutípusok a vidéki Magyarországon. In Bognár L. - Csizmady A. - Tamás P. - Tibori T. (szerk.) Nemzetfelfogások - Falupolitikák. Budapest: Új Mandátum - MTA SZKI, 141-152.

Megyesi B. (2007) A magyar lakosság vidékkel kapcsolatos attitűdjei. In Kovách I. (szerk.) Vidékiek és városiak. A tudás-és imázshasználat hatásai a vidéki Magyarországon. Budapest: L’Harmattan - MTA PTI, 27-45.

Megyesi B. (2014) Fejlesztéspolitika helyben: a társadalmi tőke és a fejlesztéspolitika összefüggései a vasvári és a lengyeltóti kistérségben készült esettanulmányok alapján: [doktori tézisek]. Socio.hu, 4(3), 100-109. 
Megyesi B. (2015) A társadalmi tőke negatív hatásai. Századvég, 20(78), 103-122.

Mormont, M. (1987) Rural Nature and Urban Natures. Sociologia Ruralis, 27(1), 1-20. https://doi.org/10.1111/j.1467-9523.1987.tb00314.x.

Mormont, M. (1990) Who is rural? or How to be Rural: Towards a Sociology of the Rural. In Marsden, T. - Lowe, P. - Whatmore, S. (eds.) Rural Restructuring. London: David Fulton, 21-44.

Ostrom, E. (2011) Background on the Institutional Analysis and Development Framework. Policy Studies Journal, 39(1), 7-27. https://doi.org/10.1111/j.1541-0072.2010.00394.x.

Putnam, R. - Leonardi, R. - Nanetti, R. (1993) Making Democracy Work: Civic Traditions in Modern Italy. Princeton: Princeton University Press.

Short, B. (2006) Idyllic ruralities. In Cloke, P. - Marsden, T. - Mooney, P. (szerk.) Handbook of Rural Studies, SAGE, 133-148.

Sík E. (2006) Tőke-e a kapcsolati tőke, s ha igen, mennyiben nem? Szociológiai Szemle, (2), 72-95.

Szreter, S. - Woolcock, M. (2004) Health by association? Social capital, social theory, and the political economy of public health. International Journal of Epidemiology, 33(4), 650-667. https://doi.org/10.1093/ije/dyh013.

Tardos R. (1995) Kapcsolathálózati elemzés: új paradigma? Szociológiai Szemle, (4), 73-80.

Tönnies, F. (2004) Közösség és társadalom. Budapest: Gondolat.

Wirth, L. (1973) Az urbanizmus mint életmód. In Szelényi I. (szerk.) Városszociológia. Budapest: Közgazdasági és Jogi Könyvkiadó. 41-64. 